\title{
Biosynthesis of oleandomycin by Streptomyces antibioticus: influence of nutritional conditions and development of resistance
}

\author{
Carmen Vilches, Carmen Méndez, Carlos Hardisson and José A. Salas* \\ Departamento de Biologia Funcional (Area Microbiologia), Universidad de Oviedo, 33006 Oviedo, Spain
}

(Received 2 November 1989; revised 21 February 1990; accepted 16 March 1990)

\begin{abstract}
The influence of different nutritional compounds on oleandomycin biosynthesis by Streptomyces antibioticus was studied, resulting in the design of a chemically defined medium for production of the antibiotic. Of the variety of carbon and nitrogen compounds tested, fructose and aspartic acid (carbon and nitrogen sources, respectively) supported the highest oleandomycin titres. Addition of propionate but not acetate, both precursors of the skeleton of the macrolide lactone ring, stimulated the biosynthesis of the antibiotic. Oleandomycin biosynthesis was repressed by glucose but not by phosphate. $S$. antibioticus develops oleandomycin resistance shortly before the antibiotic begins to be synthesized, showing a triphasic pattern of resistance: spores and producing mycelium are resistant, while non-producing mycelium is sensitive.
\end{abstract}

\section{Introduction}

Antibiotics are secondary metabolites synthesized by pathways which are often connected and influenced by primary metabolism (Drew \& Demain, 1977). Thus, frequently an intermediate metabolite from primary metabolism serves as precursor for the biosynthesis of the antibiotic. Therefore, the composition of the culture medium, closely connected with the metabolic capacities of the producing organism, greatly influences the biosynthesis of antibiotics. Changes in the nature and concentration of carbon and nitrogen sources, phosphorus concentration and trace elements have been reported to affect antibiotic biosynthesis in different organisms (for a review see Martin \& Demain, 1980).

Oleandomycin is a macrolide antibiotic produced by Streptomyces antibioticus. Structurally, it contains a macrocyclic lactone ring of 14 carbon atoms with one sugar, oleandrose, and one amino sugar, desoxamine, attached to the lactone ring. Because of our interest in oleandomycin biosynthesis, we have initiated studies to establish the nutritional factors that would support growth and high oleandomycin titres by this organism. This report describes a series of experiments in the development of a defined medium for the biosynthesis of this macrolide, the influence of different factors on the regulation of oleandomycin biosynthesis and the development of oleandomycin resistance.

\section{Methods}

Organisms and culture conditions. Streptomyces antibioticus ATCC 11891 was routinely sporulated on GAE solid medium plates and the spores, obtained as described by Hardisson et al. (1978), were suspended in $20 \%(\mathrm{w} / \mathrm{v})$ glycerol and stored at $-20{ }^{\circ} \mathrm{C}$ until used. Inocula were prepared by inoculating $50 \mathrm{ml}$ YEME liquid medium in $250 \mathrm{ml}$ Erlenmeyer flasks with $50 \mu \mathrm{l}$ spore suspension (approximately $10^{9}$ spores). After incubation at $30^{\circ} \mathrm{C}$ for $24 \mathrm{~h}$ in an orbital incubator with shaking at 250 r.p.m., the mycelia were harvested and washed by centrifugation in $50 \mathrm{~mm}$-Tris/ $\mathrm{HCl}$ buffer $(\mathrm{pH} \mathrm{7.5)}$ and then suspended to the original volume in the same buffer. Portions of this suspension were used as inocula. Micrococcus luteus ATCC 10240 was used as the indicator organism; it was grown overnight at $37^{\circ} \mathrm{C}$ in tryptone soya broth (TSB) medium (Oxoid), then diluted 1:100 in TSB containing $50 \%(\mathrm{w} / \mathrm{v})$ glycerol and stored at $-20^{\circ} \mathrm{C}$ until used.

Basal medium for nutritional studies. For studies of antibiotic production, a basal mineral-based medium was used. This contained 0.1 M-MOPS buffer, pH 7.5, 2 mM- $\mathrm{MgSO}_{4}, 0.5 \mathrm{~mm}-\mathrm{K}_{2} \mathrm{HPO}_{4}$ and $1 \mathrm{ml}$ trace salts stock solution (containing $4 \mathrm{mg} \mathrm{ZnCl} 2,20 \mathrm{mg} \mathrm{FeCl}{ }_{3} .6 \mathrm{H}_{2} \mathrm{O}$, $1 \mathrm{mg} \mathrm{CuCl} 2.2 \mathrm{H}_{2} \mathrm{O}, 1 \mathrm{mg} \mathrm{MnCl} 2.4 \mathrm{H}_{2} \mathrm{O}, 1 \mathrm{mg} \mathrm{Na}{ }_{2} \mathrm{~B}_{4} \mathrm{O}_{7} .10 \mathrm{H}_{2} \mathrm{O}$ and $1 \mathrm{mg}\left(\mathrm{NH}_{4}\right)_{6} \mathrm{Mo}_{7} \mathrm{O}_{24} \cdot 4 \mathrm{H}_{2} \mathrm{O}$ per $100 \mathrm{ml}$ of distilled water) per litre. Carbon and nitrogen sources were then added at appropriate concentrations. For the experiments, $50 \mathrm{ml}$ medium in a $250 \mathrm{ml}$ Erlenmeyer flask containing a stainless steel spring coil was inoculated with $500 \mu \mathrm{l}$ of a preinoculum prepared as described above and then incubated at $30^{\circ} \mathrm{C}$ in an orbital incubator with shaking (250 r.p.m.).

Determination of growth. Growth was determined using a method previously described (Braña et al., 1985), as follows. At different times, samples $(0.5 \mathrm{ml})$ were removed from the cultures and added to tubes containing $0.5 \mathrm{ml} 2.5 \mathrm{M}-\mathrm{HCl}$. The tubes were left to stand at room temperature for $10 \mathrm{~min}$, then $3 \mathrm{ml}$ distilled water was added and the 
suspension was homogenized by ultrasonic treatment for $30 \mathrm{~s} . \mathrm{OD}_{600}$ was then determined and the values converted to dry weight of cells $\mathrm{ml}^{-1}$ by means of a standard curve.

Determination of oleandomycin. At different times of incubation, samples $(1 \mathrm{ml})$ were removed, centrifuged at $12000 \mathrm{~g}$ for $5 \mathrm{~min}$ in an Eppendorf minifuge and, to reduce variations among different samples, the supernatant was stored at $-20^{\circ} \mathrm{C}$ until all the samples from the same experiment could be assayed together; then, portions of the supernatants were tested for oleandomycin production by bioassay against $M$. luteus as follows. $M$. luteus cell suspension $(150 \mu \mathrm{l})$ was added to $100 \mathrm{ml}$ prewarmed $\left(55^{\circ} \mathrm{C}\right)$ TSB solid medium at half nutrient concentration containing $1 \%(\mathrm{w} / \mathrm{v})$ agar. The mixture was poured onto Petri dishes and, after cooling, Whatman AA discs ( $8 \mathrm{~mm}$ in diameter) containing 5 to $20 \mu \mathrm{l}$ of the supernatant were placed on the top of the agar. In some experiments, when the level of antibiotic production was low, Oxford cylinders ( $8 \mathrm{~mm}$ in diameter) were used containing 100 to $200 \mu \mathrm{l}$ of supernatant. The plates were placed at $4^{\circ} \mathrm{C}$ for $2 \mathrm{~h}$ to allow diffusion of the antibiotic and then incubated for $16 \mathrm{~h}$ at $37^{\circ} \mathrm{C}$. The haloes were measured and correlated with a standard curve made with commercial oleandomycin using either discs or Oxford cylinders. Each determination was run in duplicate. $M$. luteus is very sensitive to oleandomycin; it is possible to detect at least $0.5 \mu \mathrm{g}$ oleandomycin (ml culture supernatant) $)^{-1}$.

In some experiments, oleandomycin was also determined by highpressure liquid chromatography (HPLC) using a reverse-phase $\mathrm{C}_{18}$ column (Novapak). Samples (5 to $20 \mu \mathrm{l}$ ) were introduced and the column developed with a mobile phase consisting of acetonitrile/ 50 mM-phosphate buffer ( $\mathrm{pH} 7.0 ; 50: 50, \mathrm{v} / \mathrm{v}$ ). The monitoring wavelength was set at $214 \mathrm{~nm}$.

Uptake experiments. For studies of fructose and aspartic acid uptake, samples were centrifuged at $12000 \mathrm{~g}$ for $5 \mathrm{~min}$ at $4{ }^{\circ} \mathrm{C}$, washed twice in 100 mM-MOPS buffer ( $\mathrm{pH} \mathrm{7.5)}$ and suspended in the same buffer. Samples $(0.5 \mathrm{ml})$ were then incubated at $30^{\circ} \mathrm{C}$ for $5 \mathrm{~min}$ and the uptake experiment initiated by adding $\left.0 \cdot 1 \mathrm{mM}\left(2 \mu \mathrm{Ci} \mathrm{ml}^{-1}\right) \mathrm{D}-[6(n))^{3} \mathrm{H}\right]$ fructose (Amersham; sp. act. $1 \mathrm{Ci} \mathrm{mmol}^{-1}=37 \mathrm{GBq} \mathrm{mmol}^{-1}$ ) or $\mathrm{L}-\left[2,3-{ }^{3} \mathrm{H}\right]$ aspartic acid (New England Nuclear; sp. act. $14.9 \mathrm{Ci} \mathrm{mmol}^{-1}=0.55$ $\mathrm{TBq} \mathrm{mmol}^{-1}$ ). After incubation at $30^{\circ} \mathrm{C}$ for $5 \mathrm{~min}$, the uptake was terminated by adding $10 \mathrm{ml}$ buffer and immediately filtering through Whatman GF/A glass-fibre filters. After washing twice with $10 \mathrm{ml}$ buffer, the filters were dried and the radioactivity estimated in a toluene-based scintillation fluid.

Oleandomycin resistance. At intervals during growth, samples of the cultures were removed and washed in $50 \mathrm{~mm}$-Tris/ $\mathrm{HCl}$ buffer $(\mathrm{pH} \mathrm{7 \cdot 5)}$. Then, they were briefly sonicated $(5 \mathrm{~s})$ to disrupt the mycelia into small fragments. Dilutions of the sonicated samples were spread over GAE plates containing either no oleandomycin, or 50 or $100 \mu \mathrm{g}$ oleandomycin ml-1. Plates were incubated at $30^{\circ} \mathrm{C}$ for $48 \mathrm{~h}$ and then the number of colony-forming units determined. Resistance was calculated as the percentage of colonies surviving in plates containing antibiotic with respect to the control plates without oleandomycin.

Thin-layer chromatography. Antibiotic activity in the culture supernatants was also analysed by ascending thin-layer chromatography and bioautography. Samples of the supernatants were developed in silica gel $\mathrm{F}_{254}$ (Merck) using as solvent $n$-butanol/acetic acid/water $(60: 20: 20$, by vol.). After developing, oleandomycin was detected by staining with $10 \%(\mathrm{w} / \mathrm{v}) \mathrm{H}_{2} \mathrm{SO}_{4}$ and heating the chromatogram for $20 \mathrm{~min}$ at $80^{\circ} \mathrm{C}$. Parallel samples were assayed by bioautography against $M$. luteus.

Analytical methods. D-Fructose was determined by oxidation with alkaline copper (Somogyi, 1952). L-Aspartic acid was measured by HPLC using a reverse-phase $\mathrm{C}_{18}$ column (Novapak); the amino acid was previously derivatized with Fluoropa as described by Hill et al.
(1979) and the mobile phase consisted of methanol/50 mM-sodium acetate (pH 5.9) $(35: 65, \mathrm{v} / \mathrm{v})$.

\section{Results}

\section{Nature of the antibiotic synthesized by S. antibioticus}

The nature of the antibiotic synthesized by $S$. antibioticus was determined by several procedures. Samples of the culture supernatants in different complex and synthetic media were analysed by thin-layer chromatography as described in Methods. After developing, the antibiotic activity was assayed by bioautography of the plates against $M$. luteus and only one zone was detected which was inhibitory to the growth of the test organism but allowed the growth of a Staphylococcus aureus MLSresistant strain (cross-resistant to macrolides, lincosamides and streptogramins B). This zone comigrated with commercial oleandomycin as demonstrated by staining of a parallel sample. In addition, the culture supernatants were analysed by HPLC and only one peak was detected having antibiotic activity which corresponded to oleandomycin. Similar results were obtained when the antibiotic synthesized in solid media was extracted from the agar and analysed as above.

\section{Influence of carbon and nitrogen sources on oleandomycin biosynthesis}

A number of carbohydrates were tested as the only carbon source for oleandomycin production in the basal mineral salts medium containing asparagine as nitrogen source (Table 1). In this, and in the remaining

\section{Table 1. Effect of carbohydrates on growth and oleandomycin biosynthesis}

The organism was grown in the basal mineral salts medium containing $15 \mathrm{mM}$-L-asparagine as nitrogen source and the specified carbon source at $55 \mathrm{~mm}$. Data represent values obtained after $72 \mathrm{~h}$ incubation at $30^{\circ} \mathrm{C}$ and are the mean of two determinations. No growth occurred when maltose or lactose was used as the carbon source.

\begin{tabular}{lccc}
\hline \hline \multirow{2}{*}{$\begin{array}{c}\text { Carbon } \\
\text { source }\end{array}$} & $\begin{array}{c}\text { Dry weight } \\
\text { of mycelium } \\
\left(\mathrm{mg} \mathrm{ml}^{-1}\right)\end{array}$ & \multicolumn{2}{c}{ Concn of oleandomycin } \\
\cline { 4 - 4 } \cline { 3 - 4 } & 2.66 & 3.00 & 1.13 \\
Fructose & $\left.2.6 \mathrm{gl}^{-1}\right)$ & {$\left[\mu \mathrm{g}(\mathrm{mg} \text { dry weight })^{-1}\right]$} \\
Galactose & 0.76 & 2.25 & 2.96 \\
Cellobiose & 0.76 & 1.50 & 1.97 \\
Xylose & 0.89 & 1.50 & 1.67 \\
Melibiose & 1.14 & 1.90 & 1.67 \\
Sucrose & 1.01 & 1.20 & 1.19 \\
Glucose & 7.34 & 0.75 & 0.10 \\
Soluble starch & 7.60 & 1.50 & 0.20 \\
Glycerol & 9.50 & 1.20 & 0.13 \\
Trehalose & 9.11 & 0.95 & 0.10 \\
\hline \hline
\end{tabular}


Table 2. Effect of amino acids and inorganic salts on growth and oleandomycin biosynthesis

The organism was grown in the basal mineral salts medium containing $55 \mathrm{~mm}$-fructose as carbon source and the specified nitrogen source at $15 \mathrm{mM}$. Data represent values obtained after 72 $\mathrm{h}$ of incubation at $30^{\circ} \mathrm{C}$ and are the mean of two determinations.

\begin{tabular}{|c|c|c|c|}
\hline \multirow{2}{*}{$\begin{array}{l}\text { Nitrogen } \\
\text { source }\end{array}$} & \multirow{2}{*}{$\begin{array}{l}\text { Dry weight } \\
\text { of mycelium } \\
\left(\mathrm{mg} \mathrm{ml}^{-1}\right)\end{array}$} & \multicolumn{2}{|c|}{ Concn of oleandomycin } \\
\hline & & $\left(\mu \mathrm{g} \mathrm{ml}^{-1}\right)$ & [ $\left.\mu \mathrm{g}(\mathrm{mg} \text { dry weight })^{-1}\right]$ \\
\hline Aspartic acid & 1.50 & $4 \cdot 50$ & 3.00 \\
\hline $\mathrm{NaNO}_{3}$ & 1.65 & $4 \cdot 35$ & $2 \cdot 64$ \\
\hline Lysine & $6 \cdot 46$ & $4 \cdot 35$ & 0.67 \\
\hline Asparagine & $2 \cdot 46$ & 2.68 & 1.09 \\
\hline Proline & $6 \cdot 27$ & 1.90 & 0.30 \\
\hline Urea & $3 \cdot 20$ & 1.90 & 0.59 \\
\hline Alanine & 3.80 & 1.50 & 0.39 \\
\hline $\mathrm{NH}_{4} \mathrm{NO}_{3}$ & $3 \cdot 23$ & 0.97 & 0.30 \\
\hline Glycine & 0.38 & 0.87 & $2 \cdot 29$ \\
\hline Threonine & $1 \cdot 28$ & 0.65 & 0.51 \\
\hline Valine & 6.83 & 0.60 & 0.09 \\
\hline Glutamic acid & $2 \cdot 47$ & 0 & 0 \\
\hline Arginine & 1.80 & 0 & 0 \\
\hline Histidine & $1 \cdot 15$ & $\mathbf{0}$ & 0 \\
\hline
\end{tabular}

experiments for the selection of a defined medium for antibiotic production, the mode of growth of the culture was noted, so as to avoid media producing too much clumping of the mycelia.

Several carbohydrates (fructose, galactose, cellobiose, xylose and melibiose) supported good levels of oleandomycin production, although to different extents. Fructose was a better carbon source than the other carbohydrates tested since it allowed production of both high oleandomycin titres and high yields of biomass. In addition, the mycelia in this carbon source had a more disperse mode of growth. In all the assays, the $\mathrm{pH}$ was also evaluated during growth and found to be relatively constant due to the buffering effect of MOPS.

Using fructose as carbon source, different compounds (amino acids, inorganic salts and urea) were tested as nitrogen sources for oleandomycin production (Table 2). Aspartic acid, lysine and $\mathrm{NaNO}_{3}$ gave the highest levels of antibiotic production.

In order to select the best combination of carbon and nitrogen sources for oleandomycin biosynthesis, an experiment was designed in which four carbon sources (fructose, galactose, glucose and soluble starch) and four nitrogen sources (aspartic acid, lysine, proline and $\mathrm{NaNO}_{3}$ ) were combined. The results (Table 3) showed that the combination of fructose and aspartic acid produced the highest oleandomycin titres and, consequently, these two compounds were chosen as carbon and nitrogen sources, respectively, for further studies.

To further explore the influence of the carbon to nitrogen ratio, the effects of different concentrations of fructose and aspartic acid on oleandomycin production
Table 3. Influence of different combinations of carbon and nitrogen sources on oleandomycin biosynthesis

The organism was grown in the basal mineral salts medium containing $55 \mathrm{~mm}$-carbon source and $15 \mathrm{~mm}$-nitrogen source. Data represent values obtained after $72 \mathrm{~h}$ of incubation at $30^{\circ} \mathrm{C}$ and are the mean of two determinations.

\begin{tabular}{|c|c|c|c|c|}
\hline \multirow[b]{2}{*}{$\begin{array}{l}\text { Carbon } \\
\text { source }\end{array}$} & \multirow[b]{2}{*}{$\begin{array}{l}\text { Nitrogen } \\
\text { source }\end{array}$} & \multirow{2}{*}{$\begin{array}{l}\text { Dry weight } \\
\text { of mycelium } \\
\left(\mathrm{mg} \mathrm{ml}^{-1}\right)\end{array}$} & \multicolumn{2}{|c|}{ Concn of oleandomycin } \\
\hline & & & $\left(\mu \mathrm{g} \mathrm{ml}^{-1}\right)$ & $\begin{array}{r}\text { [ } \mu \mathrm{g}(\mathrm{mg} \text { dry } \\
\text { weight })^{-1} \text { ] }\end{array}$ \\
\hline \multirow[t]{4}{*}{ Fructose } & Aspartic acid & 1.40 & $4 \cdot 30$ & 3.07 \\
\hline & Lysine & $6 \cdot 30$ & $4 \cdot 12$ & 0.65 \\
\hline & Proline & $6 \cdot 01$ & 1.82 & 0.30 \\
\hline & $\mathrm{NaNO}_{3}$ & 1.57 & $4 \cdot 15$ & 2.64 \\
\hline \multirow[t]{4}{*}{ Galactose } & Aspartic acid & 1.20 & 2.08 & 1.73 \\
\hline & Lysine & $3 \cdot 15$ & 3.50 & $1 \cdot 11$ \\
\hline & Proline & $2 \cdot 10$ & 2.08 & 0.99 \\
\hline & $\mathrm{NaNO}_{3}$ & 1.80 & $2 \cdot 02$ & $1 \cdot 12$ \\
\hline \multirow[t]{4}{*}{ Glucose } & Aspartic acid & 3.70 & $2 \cdot 20$ & 0.59 \\
\hline & Lysine & $6 \cdot 15$ & $3 \cdot 15$ & 0.51 \\
\hline & Proline & $4 \cdot 15$ & $3 \cdot 10$ & 0.75 \\
\hline & $\mathrm{NaNO}_{3}$ & $2 \cdot 20$ & 1.90 & 0.86 \\
\hline Soluble & Aspartic acid & $3 \cdot 50$ & 4.02 & $1 \cdot 15$ \\
\hline \multirow{3}{*}{ starch } & Lysine & $4 \cdot 20$ & $5 \cdot 08$ & 1.21 \\
\hline & Proline & $7 \cdot 15$ & $5 \cdot 40$ & 0.75 \\
\hline & $\mathrm{NaNO}_{3}$ & $3 \cdot 15$ & $4 \cdot 08$ & $1 \cdot 30$ \\
\hline
\end{tabular}

Table 4. Influence of different combinations of fructose and aspartic acid on oleandomycin biosynthesis

The organism was grown in the basal mineral salts medium containing different concentrations of fructose and aspartic acid as indicated. Data represent values obtained after $72 \mathrm{~h}$ of incubation at $30^{\circ} \mathrm{C}$ and are the mean of two determinations.

\begin{tabular}{|c|c|c|c|c|}
\hline \multirow[b]{2}{*}{$\begin{array}{l}\text { Fructose } \\
\text { (mM) }\end{array}$} & \multirow{2}{*}{$\begin{array}{l}\text { Aspartic } \\
\text { acid } \\
(\mathrm{mM})\end{array}$} & \multirow{2}{*}{$\begin{array}{c}\text { Dry weight } \\
\text { of mycelium } \\
\left(\mathrm{mg} \mathrm{ml}^{-1}\right)\end{array}$} & \multicolumn{2}{|c|}{ Concn of oleandomycin } \\
\hline & & & $\left(\mu \mathrm{g} \mathrm{ml}^{-1}\right)$ & $\begin{array}{l}\text { [ } \mu \mathrm{g}(\mathrm{mg} \text { dry } \\
\left.\text { weight })^{-1}\right]\end{array}$ \\
\hline 55 & 5 & $1 \cdot 20$ & $3 \cdot 77$ & $3 \cdot 14$ \\
\hline 55 & 10 & 1.35 & $4 \cdot 20$ & $3 \cdot 11$ \\
\hline 55 & 15 & 1.42 & 4.58 & 3.22 \\
\hline 55 & 20 & 1.48 & $4 \cdot 25$ & 2.87 \\
\hline 55 & 30 & 1.45 & $4 \cdot 10$ & $2 \cdot 83$ \\
\hline 55 & 60 & $1 \cdot 47$ & $3 \cdot 52$ & $2 \cdot 39$ \\
\hline 10 & 15 & 0.83 & $2 \cdot 27$ & $2 \cdot 74$ \\
\hline 20 & 15 & 0.95 & $2 \cdot 68$ & $2 \cdot 82$ \\
\hline 55 & 15 & $1 \cdot 37$ & $4 \cdot 38$ & $3 \cdot 20$ \\
\hline 75 & 15 & 1.54 & $4 \cdot 36$ & 2.83 \\
\hline 100 & 15 & 1.90 & $4 \cdot 23$ & $2 \cdot 23$ \\
\hline 200 & 15 & $2 \cdot 97$ & $4 \cdot 19$ & $1 \cdot 41$ \\
\hline
\end{tabular}

were tested (Table 4). Optimum concentrations were $55 \mathrm{~mm}$ and $15 \mathrm{~mm}$ for fructose and aspartic acid respectively, giving a fructose/aspartic acid ratio of 3.7.

\section{Influence of phosphate and glucose on oleandomycin biosynthesis}

Oleandomycin production was not affected much by the levels of inorganic phosphate in the medium (Fig. 1a). 


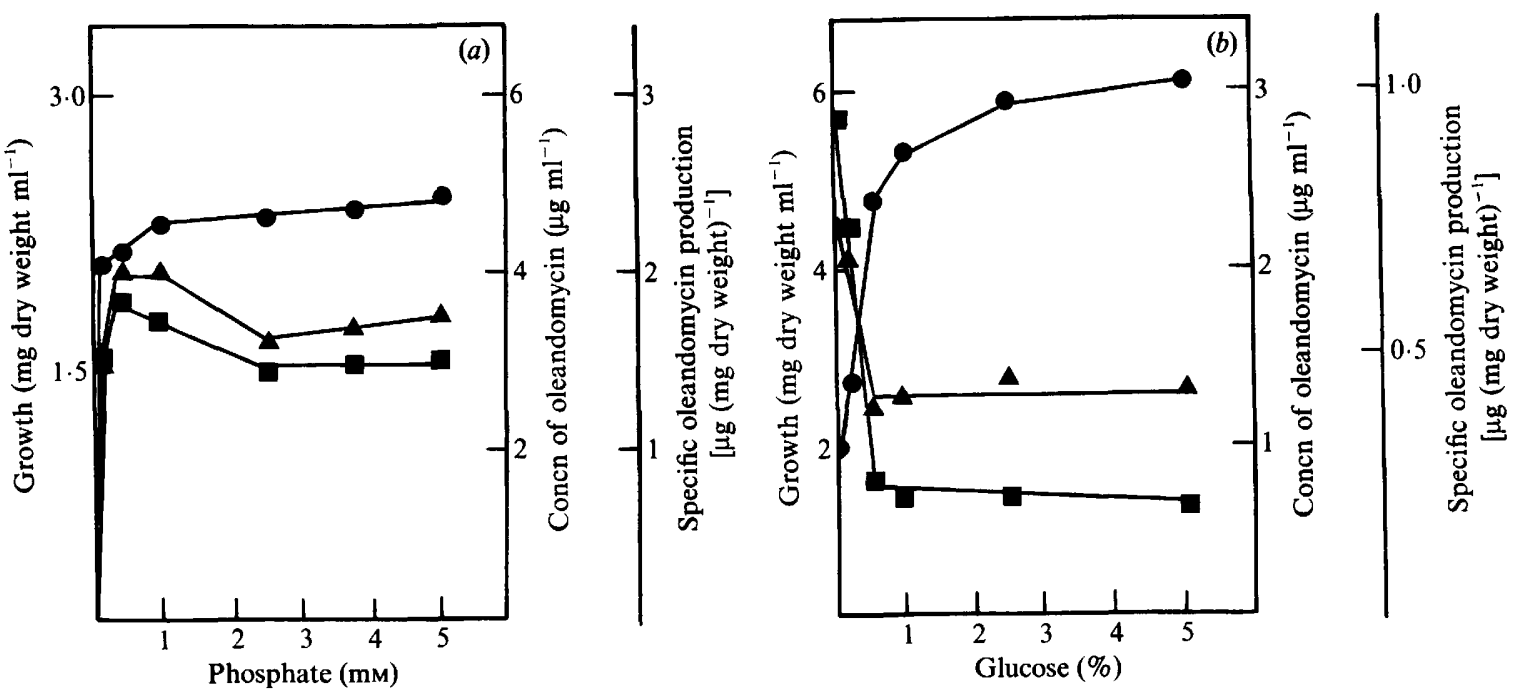

Fig. 1. Effect of phosphate (a) and glucose $(b)$ on oleandomycin biosynthesis. The organism was grown in the basal mineral salts medium containing fructose $(55 \mathrm{mM})$ and aspartic acid $(15 \mathrm{~mm})$ and supplemented with phosphate or glucose as indicated. The cultures were harvested after $72 \mathrm{~h}$ and oleandomycin titres and dry weight of the mycelium determined as described in Methods. $\bullet$, Growth; $\boldsymbol{\Lambda}$, oleandomycin; $\mathbf{w}$, specific oleandomycin production. Each value is the mean of two determinations.

Table 5. Effect of organic acids as major carbon sources on growth and oleandomycin biosynthesis

The organism was grown in the basal mineral salts medium containing $15 \mathrm{mM}$-aspartic acid as nitrogen source and the specified organic acid at $55 \mathrm{~mm}$. Data represent values obtained after $72 \mathrm{~h}$ of incubation at $30^{\circ} \mathrm{C}$ and are the mean of two determinations.

\begin{tabular}{lccc}
\hline \hline \multirow{2}{*}{$\begin{array}{c}\text { Organic } \\
\text { acid }\end{array}$} & $\begin{array}{c}\text { Dry weight } \\
\text { of mycelium } \\
\left(\mathrm{mg} \mathrm{ml}^{-1}\right)\end{array}$ & \multicolumn{2}{c}{ Concn of oleandomycin } \\
\cline { 3 - 4 } & $\left.1 \mu \mathrm{g} \mathrm{ml}^{-1}\right)$ & $\left.[\mu \mathrm{g} \mathrm{(mg} \mathrm{dry} \mathrm{weight})^{-1}\right]$ \\
\hline Pyruvate & 1.46 & 3.50 & 2.40 \\
Citrate & 0.63 & 1.90 & 3.02 \\
Succinate & 0.70 & 0.50 & 0.71 \\
Acetate & 1.65 & 0 & 0 \\
Propionate & 1.90 & 0 & 0 \\
Butyrate & 0.38 & 0 & 0 \\
\hline \hline
\end{tabular}

The optimum phosphate concentration was in the range 0.5 to $1.0 \mathrm{~mm}$ and higher levels did not produce a sharp decrease in antibiotic biosynthesis. It can, therefore, be concluded that biosynthesis of oleandomycin by $S$. antibioticus is not subject to phosphate regulation.

In contrast, the biosynthesis of oleandomycin was repressed by glucose (Fig. $1 \mathrm{~b}$ ). The addition of glucose to cultures containing fructose as the carbon source caused an increase in the rate and extent of growth but this was accompanied by a significant decrease in oleandomycin titres. Thus, antibiotic formation decreased by about $45 \%$ and $71 \%$ (oleandomycin titre and specific oleandomycin formation, respectively) in the presence of $27.5 \mathrm{~mm}$-glucose and $55 \mathrm{~mm}$-fructose.

\section{Influence of organic acids on oleandomycin biosynthesis}

Several organic acids were also tested as the sole carbon source for oleandomycin biosynthesis using aspartic acid as nitrogen source (Table 5). Only pyruvate, citrate and, to a lesser extent, succinate permitted oleandomycin biosynthesis. No antibiotic production was detected in the presence of acetate, propionate or butyrate.

Acetate and propionate are precursors of the skeleton of the lactone ring of oleandomycin: acetate as starter unit and propionate as extender unit. These two organic acids were independently added to the basal medium containing fructose and aspartic acid to determine whether they would stimulate oleandomycin production. The addition of propionate, but not acetate, caused an increase in the rate of growth (Fig. $2 b$ ), and produced the highest antibiotic titres. Specific oleandomycin production at the end of the process was $1.8,1.7$ and $2.1 \mu \mathrm{g}$ oleandomycin ( $\mathrm{mg}$ dry weight $)^{-1}$ in the control, in the presence of $10 \mathrm{~mm}$-sodium acetate and in the presence of $10 \mathrm{~mm}$-sodium propionate, respectively. Thus, the addition of $10 \mathrm{~mm}$-sodium propionate to the synthetic medium increased oleandomycin biosynthesis by about $67 \%$.

\section{Characteristics of oleandomycin biosynthesis in the synthetic medium}

The kinetic characteristics of oleandomycin biosynthesis during growth of $S$. antibioticus in the chemically defined medium are shown in Fig. 3. The stationary phase was 

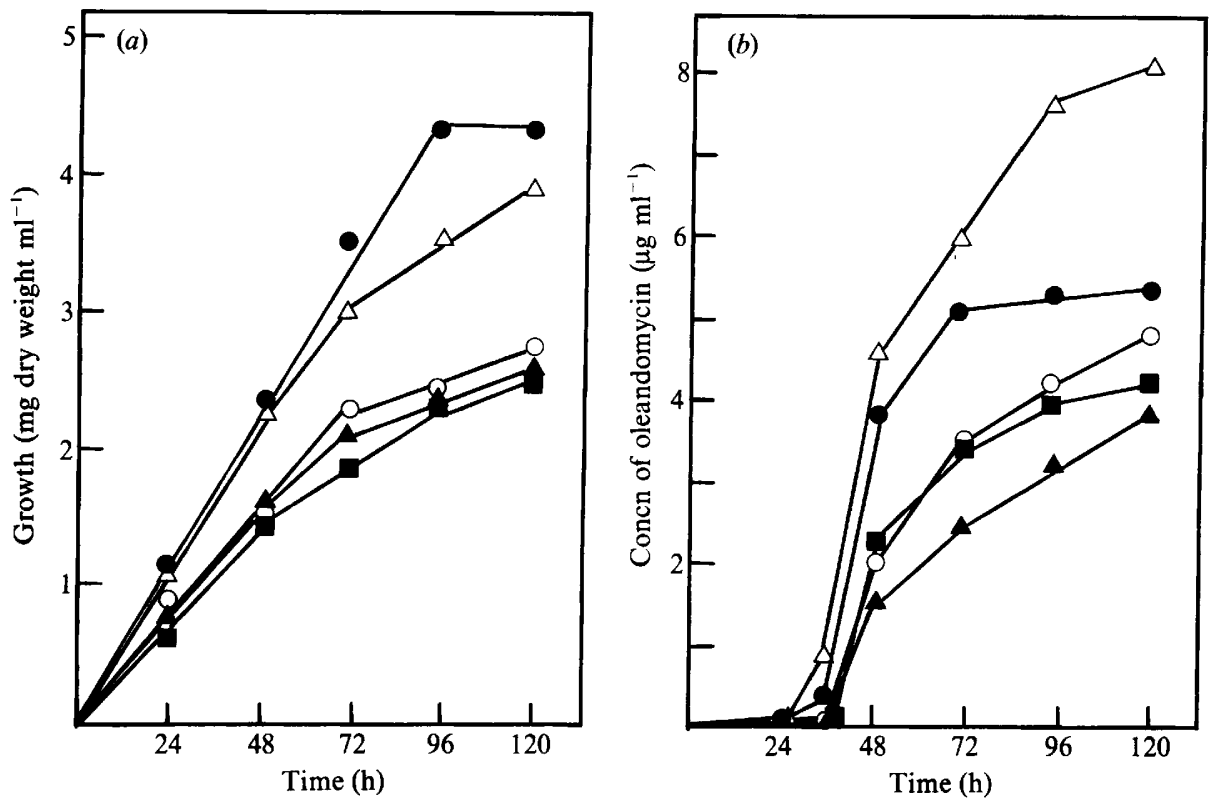

Fig. 2. Effect of the addition of propionate and acetate on growth (a) and oleandomycin biosynthesis (b). The organism was grown in the basal mineral salts medium containing fructose ( $55 \mathrm{mM})$ and aspartic acid $(15 \mathrm{mM})$ and supplemented with sodium acetate or sodium propionate as indicated. At different time intervals, samples were removed and growth and oleandomycin production determined as described in Methods. $O$, Control; $\bullet$, with $5 \mathrm{mM}$-sodium propionate; $\triangle$, with $10 \mathrm{~mm}$-sodium propionate; $\Delta$, with 5 mM-sodium acetate; a, with $10 \mathrm{~mm}$-sodium acetate. Each value is the mean of two determinations.

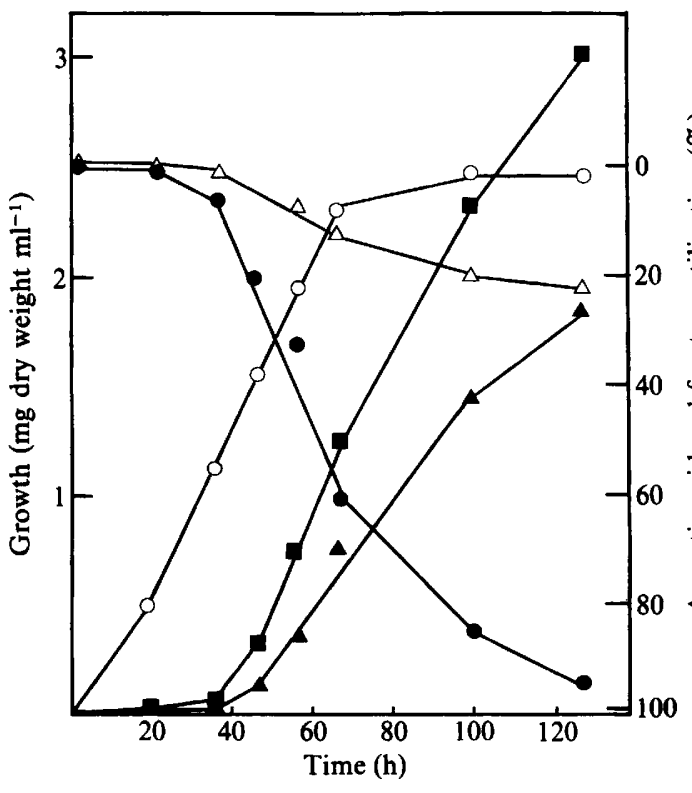

Fig. 3

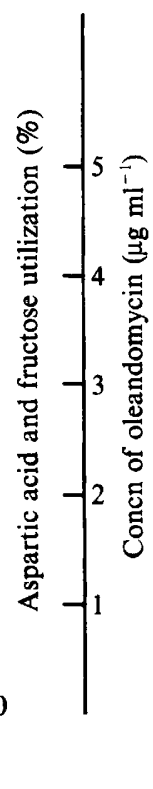

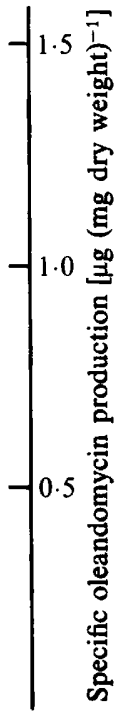

Fig. 3. Growth, carbon and nitrogen consumption and oleandomycin biosynthesis by $S$. antibioticus. The organism was grown in the basal mineral salts medium containing fructose $(55 \mathrm{~mm})$ and aspartic acid (15 mM). $\bigcirc$, Growth; $\bullet$, aspartic acid; $\triangle$, fructose; $\Delta$, oleandomycin; $\square$, specific oleandomycin production. Each value is the mean of two determinations.

Fig. 4. Fructose and aspartic acid uptake during growth of $S$. antibioticus. The organism was grown in the basal mineral salts medium with fructose $(55 \mathrm{mM})$ and aspartic acid $(15 \mathrm{~mm})$. At different times, samples were removed and pulse-labelled with tritiated fructose $\left(\square\right.$ ) or aspartic acid ( ${ }^{\circ}$ as described in Methods. Each value is the mean of two determinations. 


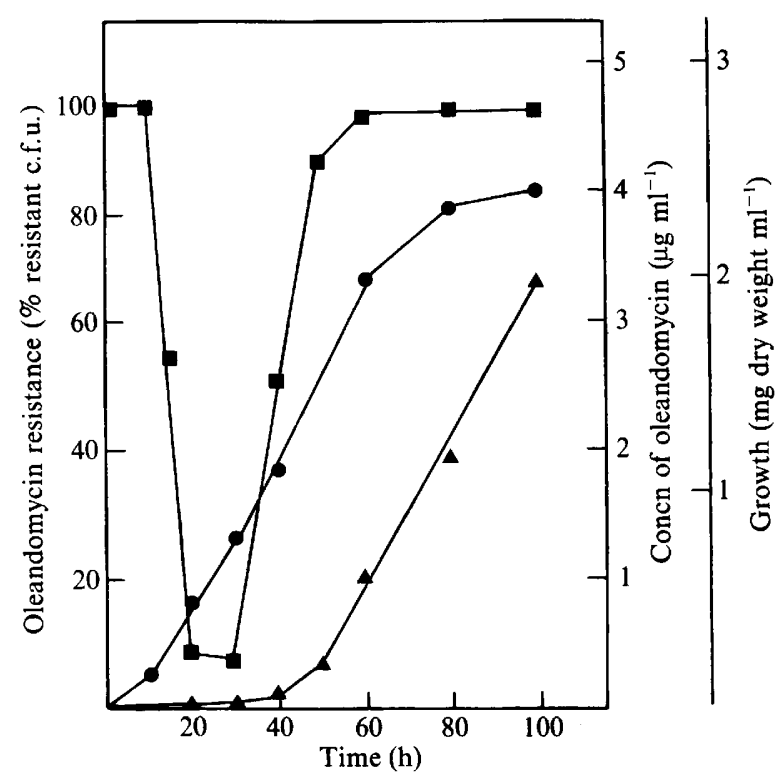

Fig. 5. Oleandomycin resistance during growth and oleandomycin biosynthesis. The organism was grown in the basal mineral salts medium containing fructose (55 mM) and aspartic acid (15 mM). At different times of incubation, samples were removed and growth (e), oleandomycin biosynthesis $(\boldsymbol{\Lambda})$ and oleandomycin resistance $(\boldsymbol{\square})$ were assayed as described in Methods. Each value is the mean of two determinations.

reached after $70 \mathrm{~h}$ of incubation and oleandomycin biosynthesis commenced at the middle of the exponential phase of growth. The nitrogen source (aspartic acid) was consumed relatively rapidly, with $50 \%$ consumption after about $60 \mathrm{~h}$. In contrast, the utilization of the carbon source (fructose) was much slower: fructose disappearance was detectable only after $55 \mathrm{~h}$ and, at the end of the experiment, only about $22 \%$ of the sugar initially supplied had been utilized.

The uptake of fructose and aspartic acid during growth was also studied. The uptake of both substrates increased during the exponential phase, reaching maximum values after $48 \mathrm{~h}$ and then sharply decreasing with the stationary phase (Fig. 4). No significant differences between the uptake of these compounds was observed.

\section{Oleandomycin resistance during growth and antibiotic biosynthesis}

The basal mineral salts medium supplemented with fructose and aspartic acid was inoculated with a spore suspension and growth and oleandomycin biosynthesis were determined. To test for resistance to the antibiotic, the number of colony-forming units surviving in plates with or without oleandomycin was examined at different stages of growth (Fig. 5)..Spores were highly resistant to oleandomycin, giving $100 \%$ survival when plated onto medium containing $100 \mu \mathrm{g}$ oleandomycin $\mathrm{ml}^{-1}$. In contrast, germinating spores and young mycelia (from 15 to $30 \mathrm{~h}$ of incubation) showed an increased susceptibility to the antibiotic: only about $8 \%$ of the mycelia survived when challenged with $100 \mu \mathrm{g}$ oleandomycin $\mathrm{ml}^{-1}$. During this period (until $30 \mathrm{~h}$ of growth), oleandomycin was not detectable in the culture supernatants: it was first detected after about $40 \mathrm{~h}$. From this time, the exponentially growing mycelia rapidly became resistant and after $60 \mathrm{~h}$ of growth no significant difference between the number of colony-forming units in plates with or without oleandomycin was observed.

The susceptibility of $S$. antibioticus to oleandomycin depending on the age of the inoculum was also tested. When spores were used as inoculum, increased oleandomycin concentrations retarded the development of the normal growth curve (Fig. 6a). This delay was also observed when the inoculum was young mycelia (about $20 \mathrm{~h}$ of growth; non-producing mycelia), although higher concentrations were necessary to produce similar delays than with spores (Fig. 6b). In contrast, cultures inoculated with older mycelia (about $50 \mathrm{~h}$; producing mycelia) grew normally (Fig. 6c).

\section{Discussion}

Our analysis of the influence of different nutritional compounds on oleandomycin biosynthesis by $S$. antibioticus has resulted in the design of a chemically defined medium suitable for growth in a fairly disperse way and for the production of reasonable amounts of this antibiotic. It consisted of mineral salts, fructose (as carbon and energy source) and aspartic acid (as nitrogen source).

S. antibioticus grew on a variety of carbon and nitrogen sources. It is known that the biosynthesis of some antibiotics and other secondary metabolites is negatively affected when a rapidly used carbon source is utilized for growth; however, when the carbon source is slowly consumed by the producer organism, the secondary metabolite is produced effectively (Demain, 1976; Drew \& Demain, 1977). This was also the situation for oleandomycin biosynthesis by $S$. antibioticus: growth with some carbon sources (i.e. glucose, glycerol, trehalose, soluble starch) led to high biomass levels, but the specific oleandomycin production was not high. Of the various carbohydrate sources tested, fructose was the most effective. Interestingly, only about $20 \%$ of this hexose was consumed at the end of the growth period. Similar results have been reported for biosynthesis of actinomycin D (Paritskaja et al., 1974; Williams \& Katz, 1977 ) and for gramicidin S (Vandamme \& Demain, 1976). In S. antibioticus, the slow fructose utilization was 


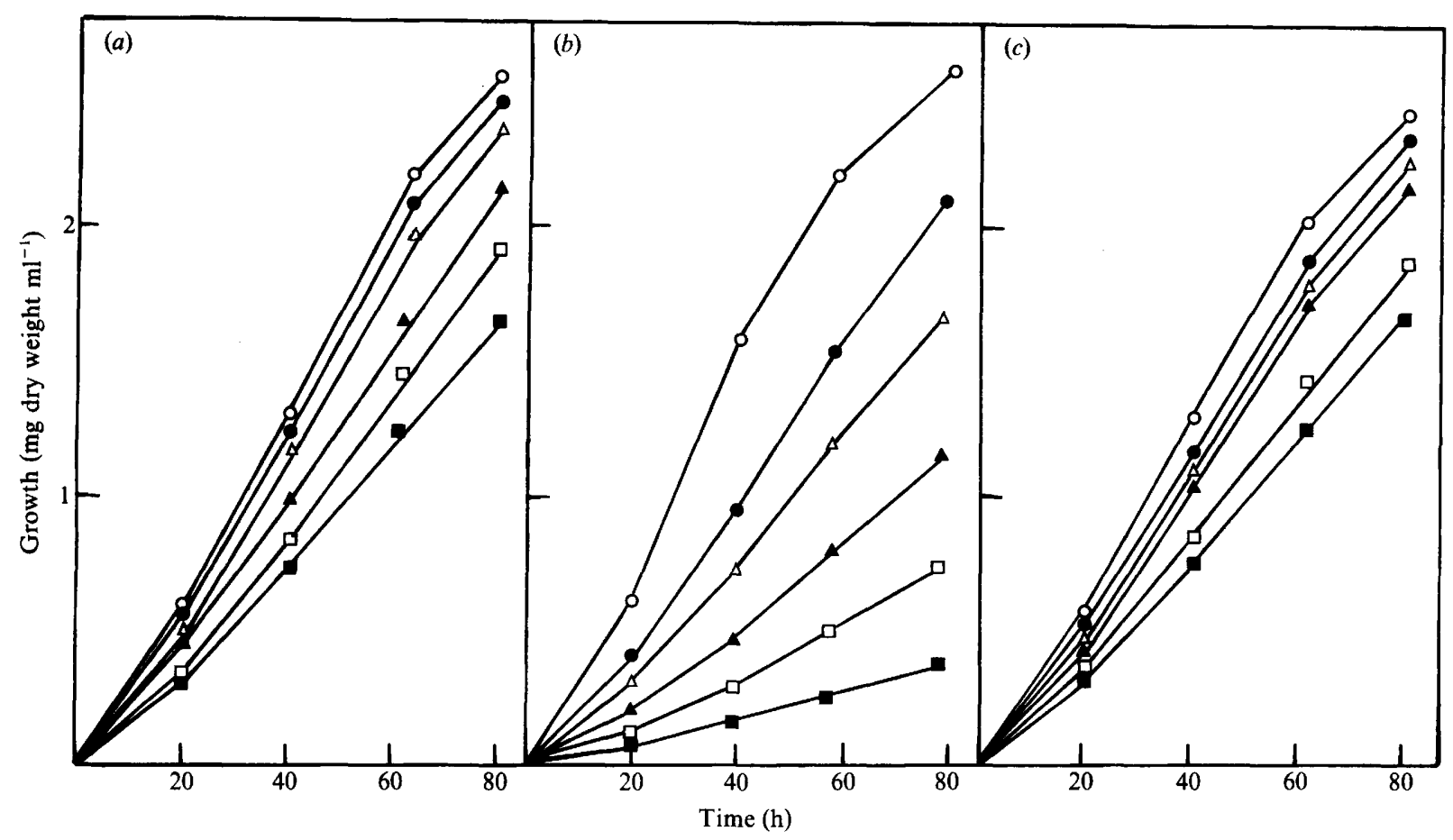

Fig. 6. Susceptibility to oleandomycin depending on the age of the inoculum. The basal mineral salts medium containing fructose ( 55 $\mathrm{mM})$ and aspartic acid $(15 \mathrm{mM})$ was inoculated with spores $(a)$, non-producing mycelium, $20 \mathrm{~h}$ of incubation $(b)$ or producing mycelium, $50 \mathrm{~h}$ of incubation $(c)$ and the growth of the cultures determined in the absence of oleandomycin $(O)$ and in the presence of $10 \mu \mathrm{g} \mathrm{ml} \mathrm{l}^{-1}$ $(\bullet), 25 \mu \mathrm{g} \mathrm{ml}^{-1}(\triangle), 50 \mu \mathrm{g} \mathrm{ml}^{-1}(\Delta), 75 \mu \mathrm{g} \mathrm{ml}^{-1}(\square)$ or $100 \mu \mathrm{g} \mathrm{ml}^{-1}(\square)$ oleandomycin. Each value is the mean of two determinations.

not due to the lack of an uptake system for this sugar, since we have shown (Salas \& Hardisson, 1981; this paper) that such an uptake system is present and active in this organism, although it requires some time for induction. On the other hand, it is possible that the nitrogen source (aspartic acid) would be preferentially used initially for growth (as both carbon and nitrogen source) and only when most of the amino acid has been exhausted (after about $60 \mathrm{~h}$ of growth) would the fructose act as the major carbon and energy source. Although a number of amino acids were favourable sources of nitrogen for oleandomycin biosynthesis, growth on one amino acid (aspartic acid) and one inorganic compound $\left(\mathrm{NaNO}_{3}\right)$ produced the highest oleandomycin titres. With these two nitrogen sources, the biomass levels were not very high, but the specific antibiotic production was the highest achieved.

Oleandomycin production by $S$. antibioticus was decreased markedly by glucose. Acidity was not responsible, since the $\mathrm{pH}$ of the medium containing increased glucose concentrations was similar to that of the control cultures. Therefore, our results strongly suggest some type of carbon catabolite control of oleandomycin biosynthesis in this organism. Whether the regulation is repression, inhibition or inactivation is not yet known. A similar situation has been reported for the biosynthesis of another macrolide, erythromycin, by Saccharopolyspora erythraea (formerly Streptomyces erythraeus) (Escalante et al., 1982).

Neither propionate nor acetate (precursors in the biosynthesis of the lactone ring of oleandomycin) were good carbon sources for oleandomycin production. However, the addition of propionate (but not acetate) to the chemically defined medium increased the biosynthesis of the antibiotic by about $67 \%$. This result probably reflects some metabolic difficulties in the synthesis of propionate, which could be a rate-limiting step in oleandomycin biosynthesis by this organism.

Growth and production of the antibiotic in the defined medium did not follow the typical pattern of a trophophase-idiophase fermentation. Thus, oleandomycin production began after $40 \mathrm{~h}$ of incubation when the organism was in the middle of the exponential phase of growth. There are many examples in the literature showing a concordance between antibiotic production and the idiophase (for a review see Weinberg, 1970). However, it is also evident in some cases that production may also parallel the growth of the producing strain (Audhya \& Russell, 1975; Williams \& Katz, 1977; Blanco et al., 1984). In order to synthesize the antibiotic 
the organism must develop a physiological change that enables it to survive during the production phase. Such a change can be constitutively expressed (Skinner \& Cundliffe, 1982; Blanco et al., 1984) or may appear only at or shortly before antibiotic production (Woodruff, 1966; Yoshida et al., 1966; Cella \& Vining, 1974; Thiara \& Cundliffe, 1988). S. antibioticus cultures in the defined medium showed a triphasic pattern of resistance: spores and producing mycelia were resistant while nonproducing mycelia were sensitive. To explain this behaviour it seems necessary to postulate the existence of a permeability barrier, probably an active efflux system which limits the access of the antibiotic to its target site. This barrier presumably does not exist in non-producing mycelium but develops just before (or simultaneously with) the onset of oleandomycin biosynthesis. Our previous studies showing the susceptibility of the ribosomes of $S$. antibioticus to oleandomycin through the growth cycle and the absence of oleandomycin-inactivating activity (Fierro et al., 1987) support this proposal. Such a mechanism of resistance has not been widely reported but has been increasingly described in the recent years (Ohnuki et al., 1985; Neal \& Chater, 1987; Fierro et al., 1988; Reynes et al., 1988).

This work was supported by a grant of the Programa Movilizador de Biotecnologia (CAICYT BT25/87). C.V. was the recipient of a grant from the Plan Nacional de Formación de Personal Investigador del Ministerio de Educación y Ciencia.

\section{References}

AudhyA, T. K. \& Russell, D. W. (1975). Enniatin production by Fusarium sambucinum: primary, secondary and unitary metabolism. Journal of General Microbiology 86, 327-331.

Blanco, M. G., Hardisson, C. \& Salas, J. A. (1984). Resistance to inhibitors of RNA polymerase in actinomycetes which produce them. Journal of General Microbiology 130, 2883-2891.

Braña, A. F., Wolfe, S. \& Demain, A. L. (1985). Ammonium repression of cephalosporin production by Streptomyces clavuligerus. Canadian Journal of Microbiology 31, 736-743.

Cella, R. \& Vining, L. C. (1984). Action of streptomycin on the growth of Streptomyces griseus. Canadian Journal of Microbiology 20, 1591-1597.

Demarn, A. L. (1976). Genetic regulation of fermentation organisms. Stadler Genetics Symposia 8, 41-55.

DREw, S. W. \& DemaIn, A. L. (1977). Effects of primary metabolites on secondary metabolism. Annual Review of Microbiology 31, 343-356.
Escalante, L., López, H., Mateos, R. C., Lara, F. \& Sánchez, S. (1982). Transient repression of erythromycin formation in Streptomyces erythraeus. Journal of General Microbiology 128, 20112015.

Fierro, J. F., Hardisson, C. \& Salas, J. A. (1987). Resistance to oleandomycin in Streptomyces antibioticus, the producer organism. Journal of General Microbiology 133, 1931-1939.

Fierro, J. F., Hardisson, C. \& Salas, J. A. (1988). Involvement of cell impermeability in resistance to macrolides in some producer streptomycetes. Journal of Antibiotics 41, 142-144.

Hardisson, C., Manzanal, M.B ., Salas, J. A. \& Suárez, J. E. (1978). Fine structure, physiology and biochemistry of arthrospore germination in Streptomyces antibioticus. Journal of General Microbiology 105, 203-214.

Hill, D. W., Walters, F. H., Wilson, T. D. \& Stuart, J. D. (1979). High-performance chromatographic determination of amino acids in the picomole range. Analytical Biochemistry 51, 1338-1341.

Martin, J. F. \& Demain, A. L. (1980). Control of antibiotic biosynthesis. Microbiological Reviews 44, 230-251.

NeAL, R. J. \& ChateR, K. F. (1987). Nucleotide sequence analysis reveals similarities between proteins determining methylenomycin resistance in Streptomyces and tetracycline resistance in eubacteria. Gene 58, 229-241.

OhNuki, T., Katoh, T., Imanaka, T. \& Aiba, S. (1985). Molecular cloning of tetracycline resistance genes from Streptomyces rimosus in Streptomyces griseus and characterization of the cloned genes. Journal of Bacteriology 161, 1010-1016.

Paritskaja, N. S., Nikitina, E. T. \& Kalakoutskil, L. V. (1974). Growth features of Actinomyces roseoflavus var. roseofungini on synthetic media with D-fructose. Mikrobiologiya 43, 686-690.

Reynes, J. P., Calmels, T., Drocourt, D. \& Tiraby, G. (1988). Cloning and expression in Escherichia coli and nucleotide sequence of a tetracycline resistance gene from Streptomyces rimosus. Journal of General Microbiology 134, 585-598.

SALAS, J. A. \& HARDISSON, C. (1981). Sugar uptake during germination of Streptomyces antibioticus. Journal of General Microbiology 125, 25-31.

SKINNER, R. H. \& CuNDlifFE, E. (1982). Dimethylation of adenine and the resistance of Streptomyces erythraeus to erythromycin. Journal of General Microbiology 128, 2411-2416.

SomoGYI, M. (1952). Notes on sugar determination. Journal of Biological Chemistry 195, 19-23.

ThiarA, A. S. \& CundlifFe, E. (1988). Cloning and characterization of a DNA gyrase B gene from Streptomyces sphaeroides that confers resistance to novobiocin. EMBO Journal 7, 2255-2259.

Vandamme, E. J. \& Demain, A. L. (1976). Nutritional requirements of the gramicidin $\mathrm{S}$ fermentation. Progress in Industrial Microbiology 17, $51-60$.

WEINBERG, E. D. (1970). Biosynthesis of secondary metabolites: roles of trace elements. Advances in Microbial Physiology 4, 1-44.

Williams, W. K. \& KaTZ, E. (1977). Development of a chemically defined medium for the synthesis of actinomycin D by Streptomyces parvulus. Antimicrobial Agents and Chemotherapy 11, 281-290.

WOODRUFF, H. B. (1966). The physiology of antibiotic production: the role of the producing organism. Symposia of the Society for General Microbiology 16, 22-46.

Yoshida, T., Weissbach, H. \& KaTZ, E. (1966). Inhibitory effect of actinomycin upon the producing organism. Archives of Biochemistry and Biophysics 114, 252-255. 